\title{
Community Participation: A Cementing Process, Theorizing Various Dimensions and Approaches
}

\author{
Nirmala Johar
}

\begin{abstract}
Published online: 24 November 2017
To cite this article: Nirmala Johar. (2017). Community participation: A cementing process, theorizing various dimensions and approaches. Journal of Construction in Developing Countries, 22(Supp. 1): 47-61. https://doi.org/10.21315/jcdc2017.22. supp 1.3

To link to this article: https://doi.org/10.21315/jcdc2017.22.supp1.3
\end{abstract}

\begin{abstract}
One of the hallmarks of urban planning in recent decades has been focused on slum upgrading through improvements in service delivery, better housing and employment policies. This paper explores community participation as an instrument in providing affordable housing for urban poor in India and abroad. Community Participation (CP) creates an appreciation of how people can present their claims in front of development agencies. There is an increasing recognition that the urban development policy framework be inclusive of the people residing in the slums and informal settlements. It is argued in the available literature that community participation and active involvement of the beneficiaries is critical to the success of a programme as people's participation advances their interests, needs, and aspirations in the development discourse. Collaborative initiatives give rise to an enabling approach through which we can achieve a more effective mobilization of community resources and skills to complement public resource allocations. We can increase well-being of deprived section of society by shifting from a needs-based approach to asset based community development. This paper focuses on conceptual framework of community participation along with successful examples of participatory models adopted by the Indian Institute of Human Settlement and Ministry of Housing and Urban Poverty Alleviation, Government of India to accomplish the target of Housing for All. The discussion will be limited to Community Participation in Slum Improvement Schemes. Various paradigms of Slum Improvement will be briefly discussed. The scope of participatory approach will be evaluated with respect to ladder of participation as established by Sherry Arnstein and Marisa B. Guaraldo Choguill. The paper also makes recommendations within administrative boundaries of institutional framework of local body and provide valuable lessons that can be applied to the implementation of the new urban Sustainable Development Goals.
\end{abstract}

Keywords: Community participation, Slums, JNNURM, RAY, Urban poor

\section{INTRODUCTION}

In September 2015, the global community adopted the new Sustainable Development Goals - one of which, Goal 11, focuses on cities and human settlements. The first target for this goal is to ensure access for all to adequate, safe, and affordable housing and basic services and upgrade slums (Patel and Bartlett, 2016). This paper describes the documentation of partnership through the practical engagement of communities of the urban poor with their governments.

Urbanization is central to India's strategy of achieving faster and more inclusive growth because agglomeration and densification of economic activities (and habitations) in urban conglomerations stimulates economic efficiencies and

Department of Architecture, DCR University of Science \& Technology, Murthal, Haryana, INDIA Corresponding author: nirmaladcr@gmail.com 
provides more opportunities for earning livelihoods. Thus, urbanization increases avenues for entrepreneurship and employment. It also enables faster inclusion of more people in the process of economic growth. The vision of India's urban growth should be guided towards inclusive, equitable, and sustainable growth of towns and cities with proper civic amenities. On the other side urbanization processes in most developing countries are intensifying. However, rapid urban population growth and the urbanization of poverty are posing unprecedented problems for government authorities. Good urbanization would ensure that towns and cities are free from slums and provides adequate opportunities for productive employment and a decent quality of life to all their inhabitants including the urban poor.

In India several policies are being implemented in urban areas to tackle the housing problem with the mission of providing affordable housing for all slumdwellers and urban poor. Jawaharlal Nehru National Urban Renewal Mission 2005 (JNNURM), with its components like Basic Services for Urban Poor (BSUP) and the Integrated Housing and Slum Development Programme (IHSDP); National Urban Housing and Habitat Policy, 2007; Affordable Housing in Partnership, 2009; Interest Subsidy Scheme for Housing the Urban Poor (ISHUP), 2009; and Rajiv Awas Yojana (RAY) and Rajiv Rinn Yojana (RRY), 2013 are some of the existing schemes, which emphasise their focus on economically weaker sections (EWS), slums, and also incorporate other weaker sections of society.

The Technical Group on the Estimation of Urban Housing Shortage has estimated the current shortage of 18.78 million dwelling units in India. The Group has also estimated that $73 \%$ of the shortage in self-occupied housing is in bottom $40 \%$ of the urban households (Ministry of Housing and Urban Poverty Alleviation, 2010). The proportion of slum dwellers in large metropolitan areas is higher. As against this huge requirement, during the seven years of implementation of the BSUP and the IHSDP component of JNNURM, only about 1.6 million dwelling units have been sanctioned. Given the huge investment required to bridge the gap between demand for affordable housing and its availability, all the costs cannot be borne by the Government and hence the key would be to attract private investment and to enable the beneficiary to increase his/her contribution. A multipronged strategy is required to meet the need for housing of the urban poor. First, a facilitative environment must be created by reviewing the regulatory processes governing land use to augment the supply of affordable housing with the help of private capital. Second, encouraging contributions from beneficiaries of the slumrehabilitation schemes are required for increasing the ownership of the programme. For this, the flow of institutional credit to the urban poor should be ensured. Third, they should be organized in suitable societies and self-help groups. Ideally, a participatory, trustful, and collaborative relationship has to be established with the community by skillfully engaging with community people (Patel et al., 2011). These measures would improve the capacity of urban poor to afford a decent shelter either through incremental improvement of their existing dwelling units. Fourth, the Government should continue to undertake and expand the slum rehabilitation programme under the overall umbrella scheme of Rajiv Awas Yojana. So the urban poor should be acknowledged as engines of economic output.

This paper is organized into five sections. The first section explores conceptual framework of community participation as developed by Sherry Arnstein, Marisa B. Guaraldo Choguill, Jules Pretty, and Sarah White and also objectives of community participation in the development context. Second section makes the case that asset based community development (ABCD) is better than needs based 
approach. $A B C D$ increases social capital and promote increased well-being of the community. Third section explores various paradigms of slum improvement along with opportunities and challenges associated in the process. Fourth section elaborates housing initiatives implemented by Ministry of Housing and Urban Poverty Alleviation, Government of India and Indian Institute of Human Settlement including examples of Baan Mankong, Thailand and Orangi Pilot Project in Pakistan. Last section ends with the conclusion that empowered community of urban poor is essential in addressing urban poverty and slums, which is crucial for sustainable economic and social development.

\section{METHODOLOGY}

The contents of this paper rely primarily on secondary sources in the form of scholarly publications and organization websites. In addition to this, publicly accessible Indian government documents from national-level ministries and from the municipal level provide key details. Limited personal communications with practitioners in urban planning and housing in India are also used.

\section{COMMUNITY PARTICIPATION: A CONCEPTUAL FRAMEWORK}

Community participation in social and urban development is advocated for various noble reasons (Botes and van Rensburg, 2000). An infinitely malleable concept, "participation" can be used to evoke and to signify almost anything that involves people (Cornwall, 2008). Many of the typologies and "ladders" of participation that have been produced focus on the intentionality, and associated approach, of those who initiate participation (Cornwall, 2008). Existing literature speaks of participation models given by Arnstein, Choguill, Pretty, and White. Arnstein's (1969) ladder looks at participation from the perspective of those on the receiving end. The different steps of participation as given by Arnstein in descending order are citizen control, delegated power, partnership, consultation, informing, placation, therapy, and manipulation. Pretty's (1995) typology of participation are manipulative participation, passive participation, participation by consultation, participation for material incentives, functional participation, interactive participation, and self-mobilization. Choguill (1996) gave a ladder of involvement composed of empowerment, partnership, conciliation, dissimulation, diplomacy, informing, conspiracy, and self-management. White (1996) gave different form of participation which is nominal, instrumental, representative, and transformative. Indeed, boundaries of participation are blurring in itself as variety of different actors in participatory processes, have a different perception of what "participation" means. For purpose of this paper community participation is defined as an active process by which beneficiary group has an impact on the direction and implementation of a development project with a view to enhance their wellbeing in terms of income and personal growth. This definition implies that the context of participation is the development project/programme. The focus is more on the participation of beneficiaries, and less on the government personnel or of donor agencies.

In the context of a development project, beneficiaries, as individuals, can be made to participate in many ways. Community Participation (CP) viewed as 
process provides a dimension that goes beyond benefit sharing, and is germane to the issue of project sustainability.

In the context of development and interpretation done by above mentioned authors, CP may be viewed as a process that serves following objectives:

1. CP may be thought of as an instrument of empowerment so that they can assess their potential and are able to initiate actions on their own and thus influence outcomes of development.

2. CP may play an active role in building beneficiary capacity in relation to a project.

3. CP may contribute to increased project effectiveness. CP tends to enhance project effectiveness when the involvement of beneficiaries contributes to better project design and implementation and leads to a better match of project services with beneficiary needs and constraints, interaction among beneficiaries, and between them and the implementing agency of the project so that delays are reduced, a smoother flow of project services is achieved, and overall costs are minimized.

4. Yet a fourth objective of CP is the desire to share the costs of the project through savings and credit when beneficiaries contribute labor, money or undertake to maintain the project. This way projects may become economically sustainable.

These objectives can be achieved with a collaborative effort of field workers, community workers drawn upon from among beneficiaries, user group, NGO and institutional support of urban local body and these objectives may overlap in real life project situations depending upon the local institutional framework at city level and development context at state level.

\section{Shift from Needs-Based Approach to Asset Based Community Development}

This section explains "traditional" (the rescuer, provider, modernizer, liberator) and "alternative" (the catalyst, facilitator, ally, advocate) roles of community development practice. The role of development agent as a Rescuer is necessary when people are unable to help themselves due to severe physical limitations (Toomey, 2011). The role of rescuer is required at the time of crisis e.g. during natural disaster phenomenon, the affected people of a given area need immediate attention of the state. But in housing up gradation programme, the role of government as a rescuer works against empowerment of the community. When the development organizations play the role of the provider in many of their activities without taking inputs from the local population, it has a disempowering effect on local populations by doing things for people instead of helping them to do things for themselves. Under "modernization" development approach the International Financial Institutions (IFIs), such as the World Bank and the International Monetary Fund, through the making of conditional zed grants and loans to poor nations and the enacting of "pro-poo"' development projects that have little reference to community or empowerment outside of the approved strategy paper (Cornwall and Brock, 2005; Kane, 2006 as cited by Toomey 201 1). The Brazilian social scientist, Paulo Freire, was one of the most prominent advocates of the role of the development agent to be one of a Liberator, and wrote extensively about the concept of the "liberation of the oppressed" from the bounds of their oppression. When the community development agent acts as a catalyst and a facilitator, they 
aim to help communities build their own capacities for identifying, emphasizing autonomous action, and self-reliance (Datta, 2007). Catalyst and Facilitator approach is different from "change agents" or "extension personnel" in that they are not promoting a particular change or new technology. The main objective of the catalyst is to spark a new idea or action, with the hope or expectation that it will lead to a change in a given direction. So the Rescuer and Provider approach works on needs-based community development while Catalyst and Facilitator approach works on asset-based community development.

Needs-based community development has the intention of advancing well-being by increasing services and establishing public policies that address the disparities (Sampson, Morenoff and Gannon-Rowley, 2002). But it inherently lacks regard for the expertise of the people in the community. Rather than employing that expertise to discover the strengths that can be exploited to increase well-being, the needs-based approach assumes that community assets are inadequate to change the fortunes of the community. As such, needs-based community development is deemed by some scholars to be a less viable model of community development when compared to asset based community development (Kretzmann and McKnight, 2005).

In contrast, asset-based community development assumes the strength of the community. This approach identifies community assets and then mobilizes leaders from within the community. It aims for individual members to feel self-efficient and capable of assisting in community change.

From Kretzmann and McKnight's 1993 book, Building Communities from the Inside Out: A Path toward Finding and Mobilizing a Community's Assets, the concept of an asset-based approach toward the goal of increasing well-being emerged. They chose to label it Asset-Based Community Development (ABCD). Contrary to the needs-based approach, this method was constructed based on the principle that "communities are not built on their deficiencies, but rather on the capacities and assets of the people and the place" (p. 35).

Identifying community assets (individuals, associations, institutions, physical environment, economic resources, and connections) empowers people to become active participants, as opposed to being passive consumers receiving services. Assets increase social capital and promote increased well-being. Although assets exist in every community, they are not necessarily used or accessed purposefully (Kretzmann and McKnight, 2005). Taken from this section, this is to say that traditional role players are inclined to dictate the terms of participation, on the other hand alternative players are more likely to ask how to help, rather than making assumptions of what to do.

\section{Various Approaches to Slum-Improvement - In-Situ Upgrading, In-Situ Land Sharing, In-Situ Redevelopment and Relocation}

This section defines slum and different responses towards slum improvement. A slum household consists of one or a group of individuals living under the same roof in an urban area, lacking one or more of the following five amenities (UN-HABITAT, 2006a):

1. Durable housing (a permanent structure providing protection from extreme climatic conditions);

2. Sufficient living area (no more than three people sharing a room); 
3. Access to improved water (water that is sufficient, affordable, and can be obtained without extreme effort);

4. Access to improved sanitation facilities (a private toilet, or a public one shared with a reasonable number of people); and

5. Secure tenure (de facto or de jure secure tenure status and protection against forced eviction.

Responses and policies towards slums improvement can be grouped into four categories: in-situ upgrading, in-situ land sharing, in-situ redevelopment, and relocation. The following sub-heads will explain the salient features of various approaches to slum-improvement.

\section{In-situ Upgrading}

Under this approach to slum-improvement, the focus is on providing basic services such as water supply, sanitation, electricity, and sewerage. To enable this, houses are sometimes realigned to create space for accommodating infrastructure and community facilities; however, an attempt is made to keep disruption at a minimum level. It is hoped that following the initial improvement on the settlement level, the slum dwellers themselves will rapidly improve their houses incrementally. Often, financial assistance is provided for building common infrastructure and for speeding up individual home improvements (Self Employed Women Academy [SEWA], 2002).

In upgrading projects, significant improvements in existing living conditions can be achieved at very low cost. Existing socio-economic fabric is maintained between the settlement and the city. Investments already made by people in their housing are protected. These features are the most important strengths of this approach. The main disadvantage of this approach is that it cannot unlock the land's commodity value in order to finance housing improvements. Since the slum remains in its original location, positive socio-economic ties with the neighborhood are not disrupted (Patel et al., 2011). It is also relatively expensive, particularly because it locks a portion of the land value for generating cross-subsidies. It can be adopted only where external finance is available.

\section{In-situ Land Sharing}

When the land is owned by private parties and having a high commercial value a commercially valuable portion of slum land is freed up to generate the funds required for paying off other claimants' land rights. Thereafter, the houses dislocated from the freed-up portion of the land are accommodated on the remaining land portion that is then owned by the community. This portion is usually upgraded or redeveloped. Since the slum remains in its original location, existing socioeconomic ties with the neighborhood are not disrupted. Unlike in-situ approach it is relatively inexpensive, particularly because it unlocks a portion of the land value for generating cross-subsidies. However, requiring some households to relocate and others not, generates organizational and collective decision-making challenges. This approach is particularly suited where the commercial value of land is relatively high (Patel et al., 2011). 


\section{In-situ Redevelopment}

This approach is very similar to in-situ land sharing but here the entire slum land is cleared, and then permanent, high-density housing is built in the commercially least attractive land portion to accommodate the slum dwellers. Finally, the commercially attractive portion of the land is developed or sold to cross-subsidize the housing for the slum community.

The chief attraction of this approach is that it provides well planned housing to slum dwellers within a short time period, without burdening public finances. It also unlocks all land value quickly, with the potential to make land use in the city more efficient. However, this approach to be financially viable, the slum's land value must be very high because the use of the freed-up land portion has to generate enough surpluses to pay for the capital-intensive construction of high-density housing for the entire slum community. So this option of slum improvement is recommended where the land value fetches high commercial gains (Patel et al., 2011).

\section{Relocation}

In this case the slum community is shifted to another site serviced with basic infrastructure and services. At the new location complete housing solutions may be provided to the community. This approach may be favored if the original site is uninhabitable (e.g. if it is prone to flooding) or if it is required for public use (e.g. for a people-affecting infrastructure project). If care is taken to ensure that slum dwellers receive secure tenure on the new site and to ensure that other factors such as new housing location and disruption of socio-economic ties do not impose unduly high costs, then this approach can be politically expedient. However, the comparatively very high cost of providing new land and housing and the difficulty of finding sufficient, affordable, and acceptable relocation sites are the shortcomings of this approach (Patel et al., 2011).

From the above discussion of various approaches to slum-improvement it should be apparent that a resource-constrained city-wide (or even state- or nationwide) programme with the ambition of improving all slums in a time bound manner cannot be confined to only one of the four approaches (UN-HABITAT and UNESCAP, 2008). To succeed, a programme must make efficient use of its resources. Therefore, it must not only allow for the use of all four approaches but also provide respective agencies with the flexibility to choose the approach that best suits a particular slum. Finally, the slum community itself should be able to influence the decision regarding which approach should be used to improve its housing settlement. Hence, the inclination of community is essential for a programme to be a great success.

Housing Initiatives by Ministry of Housing and Urban Poverty Alleviation (Govermnent of India) and IIHS (Indian Institute of Human Settlement) including examples of Baan Mankong, Thailand and Orangi Pilot Project in Pakistan.

Government of India has announced its flagship scheme to provide "Housing for All", which envisages construction of 20 million houses by 2022. Ministry of Housing and Urban Poverty Alleviation, Government of India, has implemented various housing initiatives with the assistance of joint team of Building Materials and Technology Promotion Council (BMTPC) and Housing and Urban Development Corporation (HUDCO). The strategy to achieve this goal would be through 
affordable housing, slum improvement, interest subvention, and beneficiary led construction. Considering the shortage of approximately 20 million it is imperative to adopt innovative approaches in design, planning, and use of green and sustainable eco-friendly building materials and community participation.

The following table describes different projects along with implementing agencies and development model.

Table 1. Housing Initiative by Government of India

\begin{tabular}{|c|c|c|c|c|c|}
\hline Project Name & City/State & Project Cost & $\begin{array}{l}\text { Year of } \\
\text { Sanction }\end{array}$ & No. of DU's & $\begin{array}{l}\text { Development } \\
\text { Model }\end{array}$ \\
\hline $\begin{array}{l}\text { Integrated } \\
\text { Housing and Slum } \\
\text { Development } \\
\text { Programme for the } \\
\text { Urban Poor in Slums } \\
\text { of Peddapuram } \\
\text { Municipality. }\end{array}$ & $\begin{array}{l}\text { Peddapuram, Andhra } \\
\text { Pradesh }\end{array}$ & $\begin{array}{l}\text { Rs. } 2817.60 \\
\text { Lacs }\end{array}$ & $\begin{array}{l}\text { Originally } \\
\text { sanctioned } \\
\text { in 2008-2009 } \\
\text { Revised on } \\
2011-2012\end{array}$ & 1416 & Relocation \\
\hline $\begin{array}{l}\text { Slum rehabilitation } \\
\text { for Bhimrao Nagar-1, } \\
\text { Ramdev Nagar and } \\
\text { GIDC relocation site } \\
\text { in Bhuj, Gujarat. }\end{array}$ & Bhuj, Gujarat & $\begin{array}{l}\text { Rs. } 1480.61 \\
\text { Lacs }\end{array}$ & 2013-2014 & $\begin{array}{l}300 \text { new; } 4 \\
\text { up-gradation } \\
\text { (single storied } \\
\text { units) }\end{array}$ & $\begin{array}{l}\text { In-situ re- } \\
\text { development }\end{array}$ \\
\hline $\begin{array}{l}\text { In-situ redevelopment } \\
\text { of Karimadom and } \\
\text { Poonkulam Slum, } \\
\text { Thiruvananthapuram, } \\
\text { Ph-ll. }\end{array}$ & $\begin{array}{l}\text { Thiruvananthapuram, } \\
\text { Kerala }\end{array}$ & $\begin{array}{l}\text { Rs. } 3729.40 \\
\text { Lacs }\end{array}$ & $2006-2007$ & 2680 & $\begin{array}{l}\text { In-situ re- } \\
\text { development }\end{array}$ \\
\hline $\begin{array}{l}\text { Integrated } \\
\text { Rehabilitation Project } \\
\text { for the Urban Poor } \\
\text { Staying in Slums in } \\
\text { Dangerous Locations } \\
\text { in Pimpri-Chinchwad } \\
\text { (Pune) Maharashtra. }\end{array}$ & $\begin{array}{l}\text { Pimpri - Chinchwad } \\
\text { (Pune) Maharashtra }\end{array}$ & $\begin{array}{l}\text { Rs. } 22807.74 \\
\text { Lacs }\end{array}$ & $\begin{array}{l}\text { originally } \\
\text { sanctioned } \\
\text { in 2007-2008 }\end{array}$ & 6720 & $\begin{array}{l}\text { Relocation } \\
\text { of the urban } \\
\text { poor staying } \\
\text { in slums in } \\
\text { dangerous } \\
\text { locations in } \\
\text { the city }\end{array}$ \\
\hline $\begin{array}{l}\text { Rehabilitation Project } \\
\text { for Damana and } \\
\text { Gadakana Slum, } \\
\text { Bhubaneswar, Odisha. }\end{array}$ & Odisha, Bhubaneswar & $\begin{array}{l}\text { Rs. } 745.26 \\
\text { Lacs }\end{array}$ & 2008-2009 & 192 & Relocation \\
\hline
\end{tabular}

In the housing projects listed in Table 1, following measures were adopted in providing sustainable solutions for housing the urban poor within the boundaries of objectives of community participation as discussed in the section Community Participation: A Conceptual Framework of this paper.

Community participation was mandated for effective implementation of the project by local government. The information brochure was published by Urban Local Body to bring about awareness of the scheme amongst the beneficiaries. NGOs played an important role in ensuring community participation and envisaged role in project implementation. Extensive community participation had been ensured during preparation of Detailed Project Report (DPR); from finalization of beneficiary list to dwelling unit design, site layout design, and provision of services. Slum committees are formed and engaged to implement programme and manage all finances. The dwelling units are to be constructed by community themselves. 
Building Materials Production yard had been proposed to be set up at one site to upgrade livelihood of unskilled construction workers from the slum. In some of the urban local body, the three-tier community based organization i.e. neighborhood groups (NHGs), Area Development Society (ADS) at the ward level, and The Community Development Society (CDS) formed at the Municipal level, played an integral part in this project in enhancing the community participation and effective implementation of the project.

CP was also sought in Project Life Cycle. The beneficiaries had been involved in all the stages of project life cycle i.e. from conceptualization of the project upto post construction activities. During the implementation, most of the beneficiaries were engaged in various activities of construction and finishing as per their capability. With active participation of the beneficiaries, improvements were made in respect of the technology and selection of materials, which has resulted in improved quality of assets, apart from employment generation.

Therefore, the above measures prove the argument given by Kretzmann and McKnight (2005) that community assets in terms of the practical skills, capacity, and knowledge of local residents serve as the collective resources that individuals and communities have at their disposal and these assets can be expanded as a foundation for community development. The participation was Representative and Transformative as per the forms of participation given by White (1996). As per the ladder of participation formulated by Choguill it can be viewed on the basis of above discussion that second and third highest rung on the ladder i.e. partnership and conciliation has occurred.

\section{Contribution of Indian Institute for Human Settlements (IIHS)}

In India, different paradigms of slum redevelopment schemes (SRS) have been carried out over the years. They are (i) the public private partnership model (or "Mumbai model" for its famous proposed use in Dharavi), (ii) the slum network partnership model used in Ahmadabad, and the (iii) community-managed eviction and resettlement model. The following sub-heads describe Community-Managed Eviction and Resettlement model along with two successful slum upgrading projects - Baan Makong in Thailand and the Orangi Pilot Project in Pakistan.

\section{Community-Managed Eviction and Resettlement}

A railway up gradation and improvement work was carried out under the World Bank funded-Mumbai Urban Transport Project in 2001-2002. The Bank had framed clear guidelines regarding displacement and resettlement of people affected by the projects they fund. So the project was initiated under the framework of given guidelines. Sixty thousand low-income people were resettled in permanent houses. Affected community was central to this programme. This project was unique in that (i) it did not cause economic hardship to the resettled, (ii) it was voluntary and involved no external force in implementation, and (iii) it involved the evicted households in the resettlement design, planning, and implementation. In total, it constituted a participatory, decentralized, multi-stakeholder approach to eviction and resettlement that preserved the right to housing for slum dwellers and created a sustainable relocated community (IIHS, 2011). 
It was a joint collaboration of city actors, Mumbai Metropolitan Regional Development Authority (MMRDA), the state government, the Railways Slum Dwellers Federation (RSDF), and the Alliance - a three-way partnership between Society for the Promotion of Area Resources (SPARC), the National Slum Dwellers Association, and a women's savings collective, Mahila Milan. Local governance body in the role of regulatory framework supported the slum dwellers association.

\section{Jan Kalyan Project}

In 1989, it was proposed to evict and resettle a group of slum dwellers to make way for the construction of a rail link, in government built walk-up apartments at a cost of Rs. 58,000 each. Since the cost of Rs.58, 000 caused economic hardship to the 150 affected families, the community identified vacant land adjacent to the government's relocation site, which was then allocated to these families to build their own homes. These homes cost just Rs. 16,000 at the time and were funded using housing loans. As such, self-help housing development approach was adopted by slum dwellers with external financial support (IIHS, 2011).

\section{Kanjur Marg Project}

In 1999, Indian Railways needed land for upgrading railway infrastructure, 900 families had to be resettled on an urgent basis. The affected families were involved in selecting the resettlement site, which was 1-2 kilometers away from their original homes. Families were also organized into 27 housing cooperatives that would assume responsibility for managing the operation and maintenance of resettlement housing in the future. Almost $80 \%$ of the project leaders were women, who had been saving towards secure housing for years through their savings collectives.

\section{Upgrading models of Baan Mankong and Orangi pilot projects}

Various models of upgrading have taken shape around the world. Some of the most innovative and successful models undertaken on a significant scale are the Baan Mankong project in Thailand and the Orangi pilot project in Pakistan.

\section{Baan Mankong, Thailand}

The Baan Mankong programme was launched in Thailand in January 2003 to address the housing needs of the urban slum populations. Under the programme, the government channels infrastructure subsidies and money for soft loans. Communities are responsible for managing their own budget through which they must finance infrastructure and shelter upgrades and secure land tenure for themselves (Boonyabancha, 2005).

The key players in this scheme are the Community Organizations Development Institute (CODI) (a public organization housed under the Ministry of Social Development and Human Security) and the slum communities themselves. Other actors include municipal governments, local universities, NGOs, and professionals.

The program is decentralized, in its implementation slum community's work very closely with local authorities and in conjunction with other urban development programmes. 
For a slum community to be eligible to participate, they must first set up a savings and credit group in which all residents must be members. This savings group will pool together community savings to supplement the external funds.

This programme is innovative in that it places the responsibility of identifying and acquiring land for slum upgrading projects on the slum communities themselves. This is a radical change in thinking from previous programmes - whether public housing programmes, slum upgrading or sites and services projects - where the responsibility for making land available rested squarely with the government. It is also innovative in that it takes a whole city approach to upgrading - linking slum improvement projects across the city rather than having them take place in silos. Boonyabancha (2005) argues that the programme responds to the existing reality in urban areas where the increasing commercialization of land means that land gets allocated to the highest bidder, with allocation of land to the poor taking a backseat. It also counters the argument often put forth - that there is no urban land in central locations in particular, on which to house the poor. Slum communities, acting through their community groups are responsible for finding the land on which secure tenure can be obtained. CODI then loans the money for this transaction to the community at a subsidized interest rate. CODI also loans money for shelter upgradation to community groups who they further lend the money to their members, at a slightly higher rate of interest. Using this method, more than $90 \%$ of the communities in the programme have managed to get substantially more secure tenure than before (Boonyabancha, 2005).

\section{Orangi Pilot Project}

Orangi Slum Upgradation programme has received widespread attention internationally. The Orangi Pilot Project (OPP) was launched in 1980 to overcome the constraints faced by government in upgrading slum settlements. Under this model, slum communities assume responsibility for designing, building, and financing internal sanitation infrastructure in the areas by themselves. The local government then works closely with OPP activists to provide the external infrastructure that connects their internal network to the main city pipelines. Over time, OPP activists have established themselves and now regularly negotiate with local government representatives or serve as advisors to city government officials for such upgrading projects (Hasan, 2006).

It was found that communities can finance, manage, and build provided they are given technical support and managerial guidance. Moreover, communities are able to undertake this exercise for almost a tenth of the price that it would cost local authorities. For example, what costs them Rs. 90 million (USD 1.4 million) would have cost the government Rs. 630 million (US 10.5 million) (Hasan, 2006).

This method recognizes the existing investment households have made in creating drainage and sewage networks (Hasan, 2006).

It can be concluded from above examples of Community-Managed Eviction and Resettlement model, upgrading models of Baan Mankong and Orangi pilot project and strong community participation is important, particularly the involvement of women and flexibility in key institutions and city managers can circumvent roadblocks. 


\section{CONCLUSION}

Looking at the various paradigms of Slum Improvement Schemes and successful examples of the community managed eviction and resettlement it can be concluded that local government should create more enabling environment, which means enabling the urban poor and their organizations to participate as equal partners in planning, decision-making, and development processes, including slum upgrading. In the case of supportive governments, initiatives may lead to one of the three levels of participation, empowerment, partnership, and conciliation, depending on the extent of governmental confidence in the community's ability to contribute to its own improvement. Indeed, the right to participation is enshrined in international human rights law. General Comment No. 4 (1991) of the Committee on Economic, Social and Cultural Rights (CESCR), on the Right to Adequate Housing states that governments should adopt a national housing strategy that reflects "extensive genuine consultation with, and participation by, all of those affected, including the homeless, the inadequately housed, and their representatives" (CESCR, 1991).

Affordable housing and provision of basic infrastructure in urban areas, especially slums, would generally require the intermediation of civil society, government, and private entities that can engage the community, undertake planning, reconfigure slums to enable cost-effective provision of infrastructure facilities and construct group housing colonies. Given the massive needs for affordable housing and the capacity constraints faced by urban development authorities and municipalities to take up group housing on a large scale, it is necessary to involve beneficiaries in the creation of affordable housing stock on ownership, rental or rental-cum-ownership basis and in scaling up the programme to the desired scale. There is also a need for resource mobilization and earmarking of resources by public agencies to meet the cost of affordable housing, civic infrastructure and services for the urban poor. In India, 73rd and 74th Constitutional Amendment Act lays emphasis on decentralized planning i.e. planning at local level. JNNURM also talks about Community Participation Law and creation of area sabha at local level. Hence, regulatory framework is providing "Invited Spaces" for the community and acknowledging the assets of community. The gap lies in implementation stage. The development literature calls for the mobilization and use of local resources-building materials, labour, skills, artisans, small contractors, tools, light equipment, finance, organizational capacities, and local creativity. Local resource-based employment-intensive approaches aim at optimizing employment and local resource mobilization in any given infrastructure investment (Tourne'e \& Van Esch, 2001). The case studies have shown that the combination of labour-based methods with community participation in slum upgrading presents many advantages in terms of community empowerment, job creation, and income generation. Local government should implement Local Economic Development (LED) approach, it can increase the capacities of local institutions and civil society to work together on concrete projects and improve accountability of local governments.

Urban local governments have the political, legal, and fiscal mandate to promote pro-poor slum upgrading and urban poverty reduction. They can have a substantial impact in several significant ways, including the following (Majale, 2008):

1. Planning and management of land resources, because access, location, and cost of land have significant implications for livelihood development and sustainability; 
2. Facilitating access to infrastructure and basic services, owing to health benefits versus costs of water supply and sanitation and solid waste management; and

3. Developing local economic policies that support the informal sector, MSEs and HBEs.

UNCHS (1986) Director's report stated that it is not in the interest of governments to involve their clients in designing and sharing the responsibility of development efforts. In practical terms, community participation directly benefits agencies because it broadens their resource base in physical, financial, and most important human terms.

"Clearly it is not in the interest of governments to involve their clients in designing and creating support programs and in sharing the responsibility for short-term and long-term outcomes of development efforts.

In practical terms, community participation directly benefits agencies such as social welfare departments, planning offices and local housing authorities, because it broadens their resource base in physical, financial and most important human term. It distributes or shares responsibility for the design, management, and executions of programs and projects.

Through community participation, government, despite limited outlays in per capita support, can assist a far greater number of needy than can be reached by current conventional programs."

One may argue about empowerment or partnership depending on the community freedom to initiate activities or make alliance outside the boundaries of the governmental control. The above analysis suggests, governmental attitude is essential in determining the potential results of the community effort. Self-managed projects originating from the community itself or from NGO, which succeed without external support are rare. However, it must be recognized that if Housing for All mission is to be achieved for urban poor, a stable support to the people, from the government is necessary so that community can continue managing projects by themselves.

Two important outcomes emerge from the models and practices of community participation in housing the poor in the developing countries: the objective and context of community participation. Firstly, the meaning of participation is different to the government and people. In low-cost housing schemes, an external agency conceives and designs the programme and persuades the beneficiaries to participate. Thus, the participation is to reduce the cost or increase the acceptance of the project. Such form of participation often ignores the core principle of participation of community empowerment and inclusive development. Community-based capacity needs to be developed to ensure communities are able collectively to identify problems and consider solutions.

Secondly, community participation in low income housing has always been assumed to be associated with an established area-based community such as slums and squatters and other informal settlement resident. Socio-economic context of community should be assessed so that participation in housing does not take the form of mere inclusion of residents and their labour. Empowerment through participation can be achieved by community based capacity needs to be developed to ensure communities are able to identify problems and consider solutions. It is identified 
that a better-organized and supported community are capable of addressing their own housing needs in a way that is better suited to their needs and capacities. Since community participation in India does not have a clear methodology, it lacks clear goals and objectives, is usually practiced in piece meal manner this makes the process of participation difficult to evaluate quantitatively and creates a lack accountability among development practitioners.

\section{ACKNOWLEDGEMENTS}

I whole heartedly want to acknowledge the efforts, support, guidance, and continuous motivation of Dr Jyoti Pandey Sharma, PhD supervisor, Chairperson of Department of Architecture and Town Planning, DCR University of Science and Technology and Dr Chitrarekha Kabre, Dean of Department of Architecture and Town Planning, DCR University of Science and Technology.

\section{REFERENCES}

Arnstein, S. (1969). A ladder of citizen participation. AIP Journal, 35(4): 216-224. https://doi.org/10.1080/01944366908977225

Boonyabancha, S. (2005). Baan Mankong: Going to scale with "slum" and squatter upgrading in Thailand. Environment and Urbanization, 17(1): 21-46. https:// doi.org/10.1177/095624780501700104

Botes, L. and van Rensburg, D. (2000). Nine plagues and twelve commandments. Community Development Journal, 35(1): 41-58. https://doi.org/10.1093/ cdj/35.1.41

CESCR. (1991). General comment no. 4, the right to adequate housing (sixth session, 1991). UN Doc. E/1992/23, annex III, 114. Geneva: UN.

Choguill, M.B.G. (1996). A ladder of community participation for underdeveloped countries. Habitat International, 20(3): 431-444.

Cornwall, A. (2008). Unpacking 'participation': Models, meanings and practices. Community Development Journal, 43(3): 269-283. https://doi.org/10.1093/ cdj/bsn010

Cornwall, A. and Brock, K. (2005). What do buzzwords do for development policy? A critical look at 'participation', 'empowerment' and 'poverty reduction'. Third World Quarterly, 26(7): 1043-1060. https://doi.org/10.1080/01436590500235603

Datta, D. (2007). Sustainability of community-based organizations of the rural poor: Learning from concern's rural development projects, Bangladesh. Community Development Journal, 42(1): 47-62. https://doi.org/10.1093/cdj/bsi093

Hasan, A. (2006). Orangi Pilot Project: The expansion of work beyond Orangi and the mapping of informal settlements and infrastructure. Environment and Urbanization, 18(2): 451-480. https://doi.org/10.1177/0956247806069626

Indian Institute for Human Settlements (IIHS). (2011). A background note to the discussion on "Revisiting Upgrading: Low-Income Housing and Infrastructure" for the India Urban Conference. Mysore, India, 17 November 2011.

Kane, L. (2006). The World Bank, community development and education for social justice. Community Development Journal, 43(2): 194-209. https://doi. org/10.1093/cdj/bsl043 
Kretzmann, J.P. and McKnight, J.L. (2005). Discovering community power: A guide to community participation in development: Mobilizing local assets and your organization's capacity. Evanston, IL: Asset- Based Community Development Institute, Northwestern University.

Majale, M. (2008). Employment creation through participatory urban planning and slum upgrading: The case of Kitale, Kenya. Habitat International, 32: 270-282. https://doi.org/10.1016/j.habitatint.2007.08.005

Ministry of Housing and Urban Poverty Alleviation. (2010). Report of Dr. Pronab Sen Committee on slum statistics/census. New Delhi: Ministry of Housing and Urban Poverty Alleviation, Government of India.

Patel, B., Joshi, R., Ballaney, S. and Nohn, M. (2011). Slum planning schemes: A statutory framework for establishing secure tenure and improving living conditions in Indian slums, environment and urbanization. ASIA, 2(1): 45-75. https://doi.org/10.1177/097542531000200105

Patel, S. and Bartlett, S. (2016). "We beat the path by walking" Part II: Three construction projects that advanced the learning and credibility of the Indian Alliance. Environment and Urbanization, 28(2): 1-20. https://doi. org/10.1177/0956247816644399

Pretty, J. (1995). Participatory learning forsustainable agriculture. World Development, 23(8): 1247-1263. https://doi.org/10.1016/0305-750X(95)00046-F

Sampson, R.J., Morenoff, J.D. and Gannon-Rowley, T. (2002). Assessing "neighborhood effects": Social processes and new directions in research. Annual review of participation. Development in Practice, 6(1): 6-15. https://doi.org/10.1146/ annurev.soc.28.110601.141114

Self Employed Women Academy (SEWA). (2002). Parivartan and its impact: A Partnership programme of infrastructure development in slums of Ahmadabad City. Sociology, 28(2): 443-478.

Toomey, A.H. (2011). Empowerment and disempowerment in community development practice: Eight roles practitioners play. Community Development Journal, 46(2): 181-195. https://doi.org/10.1093/cdj/bsp060

Tourne'e, J. and Van Esch, W. (2001). Community contracts in urban infrastructure works: Practical lessons from experience. Geneva: International Labor Office.

UNCHS. (1986). Global report on human settlements: 1986 (book review). Third World Planning Review, 10(4). https://doi.org/10.3828/twpr.10.4.x644q64nu67m2567

UN-HABITAT. (2006a). Analytical perspective of pro-poor slum upgrading frameworks. Nairobi: UN-HABITAT.

UN-HABITAT. (2006b). State of the world's cities 2006/7. London: Earthscan.

UN-HABITAT and UNESCAP. (2008). Housing the poor in Asian cities. Quick guides for policy makers, vol. 1-7. Available at http://www.housing-the-urban-poor.net/ QuickGuides.asp[Accessed on 1 January 2016].

White, S.C. (1996). Depoliticising development: The uses and abuses of participation. Development in Practice, 6(1): 6-15. https://doi.org/10.1080/ 0961452961000157564 